Daniela Berguio Vidotti'

Beatriz Schnabel ${ }^{2}$

MARIANE SECCO ${ }^{3}$

Priscila Cardoso Cristovam ${ }^{4}$

Ricardo Carnero Borra 5

Ismael Dale Cotrim Guerreiro da Silva ${ }^{1}$

\title{
Genetic analysis and cAMP measurement: comparison between lean and obese anovulating mice
}

\author{
Análise genética e dosagem de AMP cíclico: comparação \\ entre camundongos fêmeas anovuladoras magras e obesas
}

Original Article

Keywords

Abstract

Leptin

PURPOSE: To evaluate genes differentially expressed in ovaries from lean (wild type) and obese (ob/ob) female mice and cyclic AMP production in both groups. METHODS: The expression on messenger RNA levels of 84 genes concerning obesity was analyzed through the PCR array, and cyclic AMP was quantified by the enzyme immunoassay method. RESULTS: The most downregulated genes in the Obesity Group included adenylate cyclase-activating polypeptide type 1, somatostatin, apolipoprotein A4, pancreatic colipase, and interleukin-1 beta. The mean decrease in expression levels of these genes was around 96,40, 9, 4.2 and 3.6-fold, respectively. On the other hand, the most upregulated genes in the Obesity Group were receptor (calcitonin) activity-modifying protein 3, peroxisome proliferator activated receptor alpha, calcitonin receptor, and corticotropin-releasing hormone receptor 1. The increase means in the expression levels of such genes were 2.3, 2.7, 4.8 and 6.3-fold, respectively. The ovarian cyclic AMP production was significantly

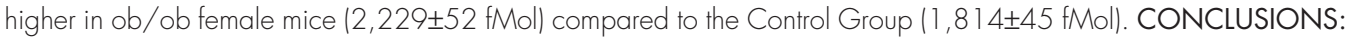
Obese and anovulatory female mice have reduced reproductive hormone levels and altered ovogenesis. Several genes have their expression levels altered when leptin is absent, especially adenylate cyclase-activating polypeptide type 1.

\section{Resumo}

OBJETIVO: Avaliar os genes diferencialmente expressos em ovários de camundongos fêmeas magras (tipo selvagem) e obesas (ob/ob) e a produção de AMP cíclico em ambos os grupos. MÉTODOS: A expressão nos níveis de RNA mensageiro de 84 genes relacionados à obesidade foi analisada por PCR Array, e o AMP cíclico foi quantificado por método imunoenzimático. RESULTADOS: Os genes que mais sofreram diminuição da expressão no Grupo Obesidade incluíram o tipo 1 de polipeptídeo ativador da adenilato ciclase, o da somatostatina, da apolipoproteína A4, da colipase pancreática e da beta interleucina 1. A média de redução na expressão desses genes foi de aproximadamente $96,40,9,4,2$ e 3,6 vezes, respectivamente. Por outro lado, os genes que mais tiveram aumento na expressão no Grupo Obesidade foram o gene da proteína modificadora da atividade do receptor de calcitonina 3, do proliferador de peroxissomos ativados por proteína alfa, do receptor de calcitonina e do receptor para hormônio liberador de corticotropinas 1. As médias de acréscimo nos níveis de expressão de tais genes foram de 2,3, 2,7, 4,8 e 6,3 vezes, respectivamente. A produção de AMP cíclico ovariana foi significantemente aumentada em camundongos fêmeas

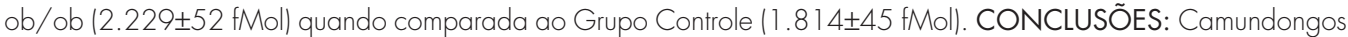
fêmeas obesas e anovuladoras possuem níveis de hormônio reprodutivo reduzidos e ovulogênese alterada. Vários genes mostram níveis de expressão alterados quando a leptina está ausente, principalmente o tipo 1 de polipeptídeo ativador da adenilato ciclase.

Correspondence

Daniela Berguio Vidotti Disciplina de Ginecologia, Departamento de Tocoginecologia, Universidade Federal de São Paulo Rua Pedro de Toledo, $781-4^{\circ}$ andar Zip code: $04039-032$ São Paulo (SP), Brazil

Received $12 / 18 / 2015$
Gynecology Discipline, Department of Tocogynecology, Universidade Federal de São Paulo - UNIFESP - São Paulo (SP), Brazil. 'Laboratory of Molecular Gynecology, Department of Gynecology, Universidade Federal de São Paulo - UNIFESP - São Paulo (SP), Brazil. 2Salomão Zoppi Diagnósticos - São Paulo (SP), Brazil.

${ }^{3}$ Human Genome Laboratory, Universidade de São Paulo - USP - São Paulo (SP), Brazil.

${ }^{4}$ Ocular Surface Advanced Center (CASO), Department of Ophthalmology, Universidade Federal de São Paulo - UNIFESP São Paulo (SP), Brazil.

${ }^{5}$ Department of Genetics and Evolution, Universidade Federal de São Carlos - UFSCar - São Carlos (SP), Brazil.

Conflict of interests: none. 


\section{Introduction}

The adipose tissue has recently been recognized as an important endocrine organ. Through the secretion of soluble factors (collectively called adipokines), this tissue may regulate several physiological processes, such as glucose and lipid metabolism, immune response, and reproduction $^{1}$. Among those adipokines, leptin seems to strongly influence on the onset of puberty and ovulatory capacity ${ }^{2}$.

Leptin is a peptide of 146 amino acids encoded by the ob gene. Its expression occurs mainly in the white adipose tissue and, in a lesser extent, in the brown one. Other structures that express this gene include hypothalamus, pituitary gland, gastric epithelium, placenta, mammary glands, and gonads ${ }^{3-7}$. Leptin controls food intake and metabolic rates according to the nutritional status. During a meal, the serum leptin concentration increases and it exerts an inhibitory action on hypothalamus, reducing appetite. The concentration of this hormone still increases during a couple of hours after the meal, and it stimulates thermogenesis to promote energy expenditure and reduce fat stocks. On the other hand, individuals deprived from food have a decrease in leptin serum concentration, which stimulates appetite and restricts energy expenditure. Leptin production is directly proportional to fat mass on the body. Obese individuals produce great amounts of leptin, but they also become hormone-resistant. Tendency of becoming leptin-resistant through chronic overfeeding is observed both in humans and animals ${ }^{8}$.

Female leptin-knockout mice (ob/ob) are sterile, indicating a role for this hormone in the control of reproductive status. They present low gonadotropin concentrations and incomplete development of reproductive organs. This phenotype is reversed by administration of exogenous leptin?. In women, the leptin serum concentration is inversely correlated with amenorrhea age $^{10}$. This hormone is also implicated in maintaining other normal female reproductive functions, including lactation, folliculogenesis, ovarian steroidogenesis, endometrial maturation, and receptivity to embrio ${ }^{11}$. Leptin may influence on the reproductive status by acting on hypothalamus and stimulating secretion of $\mathrm{GnRH}^{2,12}$. However, this stimulation does not seem to be exerted directly on GnRH-producing neurons. There is a complex interplay among different types of neurons, which produces various kinds of neuropeptides. Kisspeptin might be the strongest candidate to mediate leptin effects on hypothalamus ${ }^{2,12}$.

Although leptin receptors are expressed on ovaries ${ }^{13}$, little is known about how leptin regulates gene expression in these organs. In this work, we evaluated gene expression on ovaries from lean (wild type) and obese (ob/ob) mice, in order to determine the differentially expressed genes.
We focused our discussion on about 10 genes, and we speculated why they are up or downregulated, and how these differences in expression levels can account for the anovulatory phenotype in obese female mice.

\section{Methods}

Female C57Bl/6 (Control) and B6.V-Lep ${ }^{\mathrm{ob}} / \mathrm{J}$ (ob/ob) mice purchased from the Development Center of Medicine and Biology Experimental Models (CEDEME, acronym in Portuguese), at Universidade Federal de São Paulo (UNIFESP), were analyzed in this study. The Ethics Research Committee of UNIFESP approved all the procedures used.

Ovaries from the Control $(n=5)$ and ob/ob $(n=6)$ Groups were aseptically extracted. The organs were maintained at $-80^{\circ} \mathrm{C}$ until they were applied for total RNA extraction, using Trizol reagent (Life Technologies) and following manufacturer's instructions.

Reverse transcription was performed in a mixture containing $5 \mu \mathrm{M}$ random hexamer, $200 \mu \mathrm{M}$ dNTP, $2 \mathrm{U} / \mu \mathrm{L}$ MMLV transcriptase (Promega, Madison, WI), and $1 \mu \mathrm{g}$ RNA with the corresponding buffer at $42^{\circ} \mathrm{C}$ for $90 \mathrm{mi}$ nutes, then at $85^{\circ} \mathrm{C}$ for 10 minutes.

Real-time PCR was performed using the ABI prism 7,000 Sequence 10 Detection System (Applied Biosystems) equipped with a 96-well optical reaction plate. The reactions were set up with $16.5 \mu \mathrm{L}$ Sybr ${ }^{\circledR}$ Green PCR Master Mix (Applied Biosystems). All real-time experiments were ran in triplicate and a mean value was used for the determination of mRNA levels. Considering the anovulatory phenotype from ob/ob female mice, we attempted to establish how the absence of leptin modulates the gene expression profile in ovaries. Genes differentially expressed between controls (wild type) and obese (ob/ob) mice were determined through PCR array, using RNAs extracted from ovaries. According to the false discovery rate (FDR) approach ${ }^{14}$, nine genes were considered for analysis. The identification of differentially expressed genes between Control and ob/ob Groups was carried out using the $\Delta \Delta \mathrm{Ct}$ methodology and statistical analysis, based on unpaired Student's $t$-test. The FDR approach ${ }^{14}$ with 0.05 cutoff was used to select a list of differentially expressed genes ${ }^{15}$.

Some of the ovaries removed for RNA extraction was stored in liquid nitrogen until cyclic AMP quantification, using the cAMP Direct EIA Kit (Amersham Biosciences, NJ, USA), following manufacturer's instructions.

The difference between both groups was analyzed applying the Student's $t$-test. If data normality was confirmed, through Shapiro-Wilk's test using SPSS software (SPSS Statistics, v. 16.0, SPSS Inc., USA), it was analyzed by Mann-Whitney's test. Statistical significance considered $\mathrm{p}<0.05$. 
Results

Polymerase chain reaction array for obesity genes

Downregulated genes in obese mice included: adenylate cyclase-activating polypeptide type 1 (Adcyap1 or PACAP), somatostatin (Sst), apolipoprotein A4 (Apo A4), pancreatic colipase (CLPS), and interleukin-1 beta (IL-1 $\beta$ ). The mean decrease in expression levels of these genes was around 96, $40,9,4.2$ and 3.6-fold, respectively. On the other hand, upregulated genes in the Obesity Group were receptor (calcitonin) activity modifying protein 3 (RAMP3), peroxisome proliferator activated receptor alpha (PPARA), calcitonin receptor (CALCR), and corticotropin-releasing hormone receptor 1 (CRHR1), as seen in Figure 1. The mean increase in expression levels of those genes were 2.3, 2.7, 4.8 and 6.3-fold, respectively. The modification in expression levels from all these genes are summarized in Table 1.

\section{Cyclic AMP accumulation}

In order to determine the cellular activation status in ovaries from control and obese mice, intracellular cAMP accumulation was measured applying ELISA. The cAMP accumulation was statistically higher $(\mathrm{p}<0.01)$ in ovaries from obese mice $(2,229 \pm 52 \mathrm{fMol})$ compared to controls (1,814 $445 \mathrm{fMol}$, Figure 2).

\section{Discussion}

We demonstrated in this report that several genes have their expression levels altered when leptin is absent. We used ob/ob mice, which are genetically deprived from leptin. These mice are obese and anovulatory; they have reduced reproductive hormone levels, revealing a functional defect in the hypothalamic-pituitary axis ${ }^{16,17}$. Although it is clear that leptin stimulates ovogenesis by interfering with LH/estrogen levels, little is known about the effects that this hormone exerts over gene expression on ovaries.

In the absence of leptin, Adcyap1/PACAP, ApoA4, Sst, CLPS, and IL-1 $\beta$ are all downregulated compared to control mice (Figure 1). The most important alteration was in the expression levels of Adcyap1/PACAP, which was downregulated (96-fold) in comparison with controls. PACAP is a neuropeptide produced by mammals that have actions on the central nervous system and peripheral tissues, including intestine, lung, adrenal gland, testicles, and ovaries ${ }^{18-20}$. Moreover, its action on the hypothalamic-pituitary-gonad regulates the reproductive function. More specifically, the presence of PACAP and its receptors in the ovary stimulates

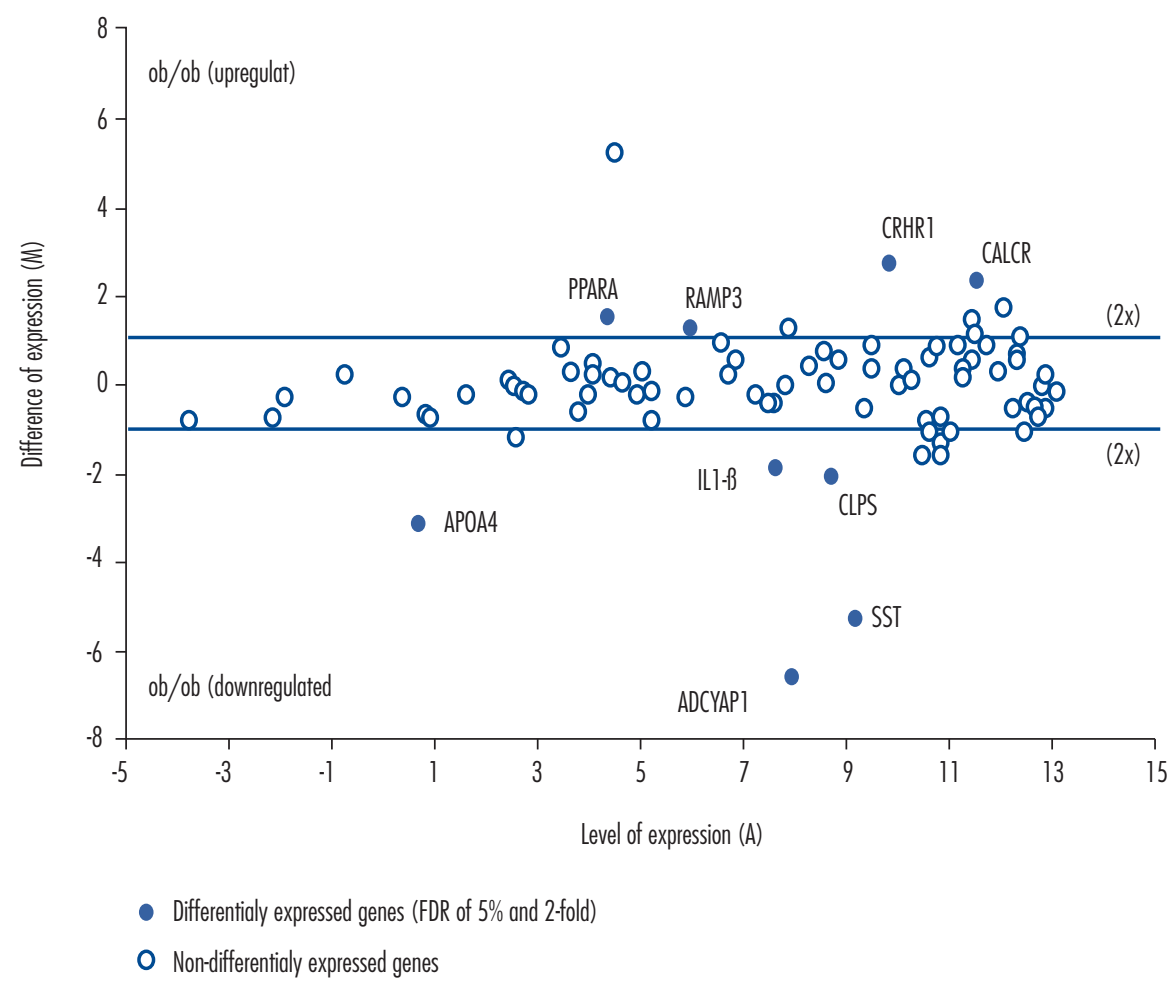

Figure 1. Schematic plot showing differentially expressed genes between control and obese female mice 
ovarian functions, including steroidoigenesis and cAMP accumulation in granulosa cells rat ${ }^{21,22}$. This peptide also accelerates meiotic maturation in mouse oocytes ${ }^{23}$.

Furthermore, PACAP contributes to granulosa cells survival through the inhibition of apoptosis in pre-ovulatory follicles ${ }^{24}$. Thus, the PACAP presence and its receptors in ovaries have marked effects on ovarian physiology, and the reduced expression of this gene may account for the anovulatory phenotype. It is intriguing that cAMP levels were greatly increased in ob/ob ovaries (Figure 2) compared to controls by the same time that PACAP, an adenylate cyclase activator, was reduced. This fact, however, can be explained because other cell signaling pathways that have cAMP as second messenger may be activated in ob/ ob ovaries. CALCR and CRHR1, both upregulated in $\mathrm{ob} / \mathrm{ob}$ ovaries, may account for this phenomenon. It has already been described that both receptors can transduce signal through cyclic AMP, although it has not been clear if both receptors are coupled do $G_{s}$ in the ovarian tissue $e^{25,26}$.

The Sst expression was downregulated (40-fold) in ovaries from obese mice, a fact that reinforces its role in metabolism and reproductive physiology. In vertebrates, the Sst is a multifunctional peptide distributed through the central nervous system and peripheral tissues, wich has a wide physiological role of neuromodulation, osmoregulation, and also affects aspects of growth, development and metabolism ${ }^{27,28}$. Sst secretion is regulated by intra/extra-pancreatic mediators and nutrients ${ }^{29}$. In addition, it inhibits the secretion of glucagon and insulin ${ }^{29,30}$. It has been reported that Sst administered

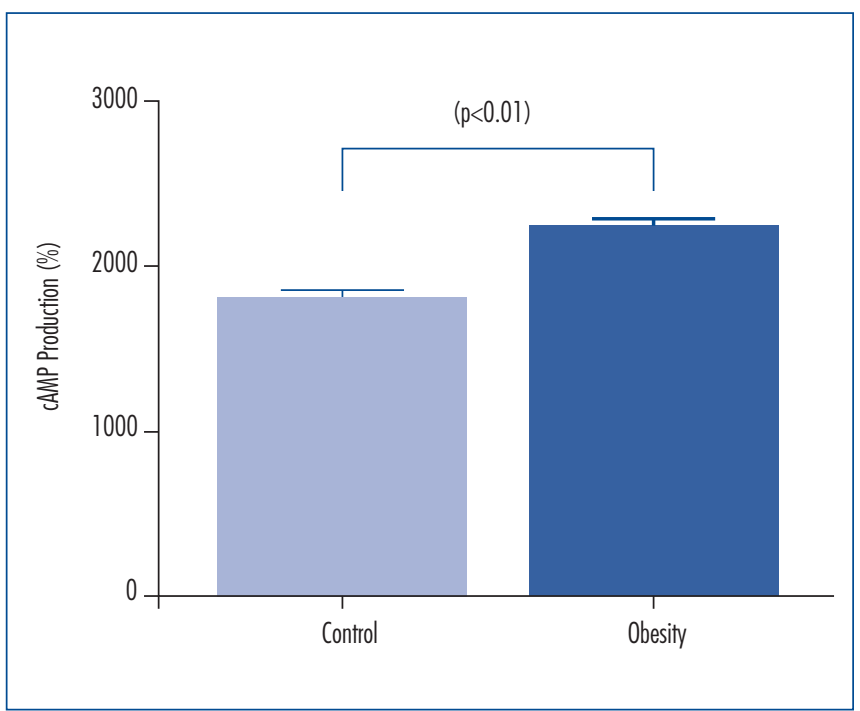

Figure 2. Determination of cAMP levels in ovaries of control and obese mice female. Enzyme immunoassay was used to determine cAMP production expressed as percentage of basal value. Data are expressed as mean \pm SEM of triplicate values and are representations of three experiments. The values of cAMP were: Control $(n=3): 1,814 \pm 45$ (fMol) and Obese ( $n=3): 2,229 \pm 52$ (fMol). The $p<0.01$ was significantly different from the Control Group value to peripubertal mice blocked the initial gonadotropinindependent process of follicle growth in vivo, suggesting that Sst might directly act on follicular component cells in the ovary ${ }^{31}$. Thus, increased Sst could account for the anovulatory phenotype. Further investigation is necessary to explain this apparent contradiction.

We observed that mRNA expression level of ApoA4 in ob/ob ovaries was reduced (9-fold) compared to controls. This finding is reinforced in the study by Liu et al. ${ }^{32}$, who observed that hypothalamic mRNA levels of ApoA 4 were significantly reduced in obese mice (ob/ob). The anorexigen gene, ApoA4, is involved in controlling food intake and body weight ${ }^{33,34}$. Furthermore, obese animals have increased satiety threshold, contributing to obesity etiology. No effects on the reproductive status exerted by Apo A4 had already been described.

IL- $1 \beta$ is also downregulated in obese mice. The IL-1 system components have several sites of synthesis in the ovary. These factors have been localized in several ovarian cell types, such as the oocyte, granulosa and theca cells and in several mammalian species. IL- 1 is involved in the ovulation process, in oocyte maturation and in several other ovulationassociated events like the synthesis of proteases, regulation of plasminogen activator activity, prostaglandin and nitric oxide production. It also regulates ovarian steroidogenesis ${ }^{35}$.

We also found some genes that were marked upregulated in ob/ob ovaries: RAMP3, PPARA, CALCR, and CRHR1.

Adrenomedullin (ADM), calcitonin gene-related peptides ( $\alpha$ - and $\beta$-CGRPs), and intermedin/adrenomedullin

Table 1. List of genes considered differentially expressed (FDR of 5\% and 2-fold or twice the level of expression as the Control Group)

\begin{tabular}{|c|c|c|c|c|c|c|c|c|}
\hline \multicolumn{2}{|c|}{ Gene bank } & $\begin{array}{l}\text { Gene } \\
\text { symbol }\end{array}$ & $\begin{array}{l}\text { Control } \\
\text { Group } \\
(\Delta \mathrm{CT}) \\
\end{array}$ & $\begin{array}{l}\text { ob/ob } \\
\text { Group } \\
(\Delta \mathrm{CT}) \\
\end{array}$ & A & $\underset{(\Delta \Delta C \mathrm{C})}{\mathbf{M}}$ & $\begin{array}{c}\text { Fold } \\
\text { regulation } \\
\left(2^{-\Delta \Delta C T}\right)\end{array}$ & p-value \\
\hline \multicolumn{9}{|c|}{ Adenylate cyclase activating polypeptide 1} \\
\hline \multirow{9}{*}{ 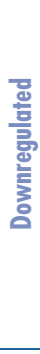 } & NM_008361 & ADCYAPI & 4.6 & 11.2 & 7.9 & -6.6 & $95.7 x$ & 0.0003 \\
\hline & \multicolumn{8}{|c|}{ Somatostatin } \\
\hline & NM_201615 & SST & 6.5 & 11.8 & 9.1 & -5.3 & $39.6 x$ & 0.001 \\
\hline & \multicolumn{8}{|c|}{ Apolipoprotein A-IV } \\
\hline & NM_009625 & APOA4 & -0.9 & 2.3 & 0.7 & -3.2 & $9.0 \mathrm{x}$ & 0.0000 \\
\hline & \multicolumn{8}{|c|}{ Colipase. pancreatic } \\
\hline & NM_007407 & CLPS & 7.7 & 9.8 & 8.7 & -2.1 & $4.2 x$ & 0.004 \\
\hline & \multicolumn{8}{|c|}{ Interleukin-1 beta } \\
\hline & NM_024435 & ILI-B & 6.7 & 8.6 & 7.6 & -1.8 & $3.6 x$ & 0.0005 \\
\hline \multicolumn{9}{|c|}{ Receptor (calcitonin) activity modifying protein 3} \\
\hline & NM_009605 & RAMP3 & 6.6 & 5.4 & 6.0 & 1.2 & $2.3 x$ & 0.0009 \\
\hline \multicolumn{9}{|c|}{ Peroxisome proliferator activated receptor alpha } \\
\hline 흠 & NM_007468 & PPARA & 5.2 & 3.7 & 4.5 & 1.4 & $2.7 x$ & 0.0001 \\
\hline \multicolumn{9}{|c|}{ Calcitonin receptor } \\
\hline 3 & NM_013732 & CALCR & 12.7 & 10.4 & 11.6 & 2.3 & $4.8 x$ & 0.0006 \\
\hline \multicolumn{9}{|c|}{ Corticotropin-releasing hormone receptor 1} \\
\hline & NM_008177 & CRHRI & 11.2 & 8.5 & 9.9 & 2.7 & $6.3 x$ & 0.0003 \\
\hline
\end{tabular}

A: (ob/ob + Control) $/ 2$ and M: (Control-ob/ob); $p<0.05$ (t-test) was significant. 
2 (IMD/ADM2) are key regulators for vascular and cardiovascular developments. Chang and $\mathrm{Hsu}^{36}$ evaluated the role of these peptides and their cognate receptors (CLR/ RAMP) in the reproduction and fetal-maternal blood circulation, gamete development, and gamete movement in the oviduct. Wang et al. ${ }^{37}$, using intrauterine assays in mice, showed that calcitonin promotes pre-implantation and development of embryos in a dose-dependent manner of intracellular $\mathrm{Ca}^{2+}$ level ${ }^{38}$. The authors correlated these findings to a significant increased gene expression of phospho-P38MAPK. They are in agreement with the concept that CLR/RAMP receptors were recruited to create a myriad of functions during the reproduction in mammals. Regarding this gene, we found that CALR was upregulated on ob/ob mice, showing the novel and important role in the regulation of lipid and glucose metabolisms and inflammation. In this article, it was seen that a closer correlation between leptin lack, obesity and overweight is significantly involved in the declining fertility and the increase of CALR provides an increase of second messengers, i.e. cyclic AMP.

Another gene that was strongly influenced in our model and was found to be upregulated was PPAR, (Peroxisome Proliferator Activated Receptor) which suppresses leptin expression in adipocytes. PPAR has many potential roles in pathological states, including atherosclerosis, inflammation, cancer, and demyelination. Herein, we present the current state of the molecular findings of PPAR action and their relationship involvement between obesity and infertility. The increased expression of this receptor may be associated with reduction of leptin as a compensatory mechanism. The phenotype infertility is associated, in part, due to PPAR effect on blastocyst implantation decrease and decidualization. Recent observations using isoforms of PPAR $\delta$ ligands unveil that it may also be an important strategy to therapeutic target disorders, including cancer, dyslipidemia and now, infertility. It is known that CRH, a 41-amino acid neuropeptide, synthesized in the hypothalamus that regulates hypothalamus-pituitary-adrenal axis, is strongly associated with stress and inflammation. The effects of $\mathrm{CRH}$ are mediated through CRHR1 and CRHR2 receptors that are implicated in several reproductive functions acting as inflammatory components. In the present study, we assessed the relative expression levels of several genes and molecules in healthy and obese/infertile ovaries, revealing the first evidence for a potential role of $\mathrm{CRH}$ receptors in infertility profile and their further association with obesity. We have showed that $\mathrm{CRH}$ receptor is significantly more expressed in the obese and infertile ovaries mice compared to wild type healthy mice. Such stress and inflammation could be further correlated to obesity, since increased infertility rates, mainly affected by modulation of the decidualization and decrease blastocyst process in ob/ob mice may, contribute to the expression of their receptors to keep a proper function of ovaries ${ }^{39}$.

In summary, this model of obese and anovulatory mice has reduced reproductive hormone levels and altered ovogenesis. Furthermore, we demonstrated in this work that several genes have their expression levels altered when leptin is absent, especially Adcyap1/PACAP. However, more studies are needed to further characterize the effects that this hormone exerts on the ovaries.

\section{Acknowledgements}

This work was supported by grants from Fundação de Amparo à Pesquisa do Estado de São Paulo (FAPESP), process number 07/55629-0.

\section{References}

1. Ahima RS. Adipose tissue as an endocrine organ. Obesity (Silver Spring). 2006; 14 Suppl 5:242s-9s.

2. Hausman GJ, Barb CR, Lents CA. Leptin and reproductive function Biochimie. 2012;94(10):2075-81

3. Zhang Y, Proenca R, Maffei M, Barone M, Leopold L, Friedman $J M$. Positional cloning of the mouse obese gene and its human homologue. Nature. 1994;372(6505):425-32.

4. Masuzaki H, Ogawa Y, Sagawa N, Hosoda K, Matsumoto T, Mise $\mathrm{H}$, et al. Nonadipose tissue production of leptin: leptin as a novel placenta-derived hormone in humans. Nat Med. 1997;3(9):1029-33.

5. Smith-Kirwin SM, O'Connor DM, De Johnston J, Lancey ED, Hassink SG, Funanage VL. Leptin expression in human mammary epithelial cells and breast milk. J Clin Endocrinol Metab. 1998;83(5):1810-3.

6. Mix H, Widjaja A, Jandl O, Cornberg M, Kaul A, Göke M, et al. Expression of leptin and leptin receptor isoforms in the human stomach. Gut. 2000;47(4):481-6.
7. Sahu A. Mini-review: a hypothalamic role in energy balance with special emphasis on leptin. Endocrinology. 2004;145(6):2613-20.

8. Michalakis K, Mintziori G, Kaprara A, Tarlatzis BC, Goulis DG. The complex interaction between obesity, metabolic syndrome and reproductive axis: a narrative review. Metabolism. 2013;62(4):457-78.

9. Chehab FF, Lim ME, Lu R. Correction of the sterility defect in homozygous obese female mice by treatment with the human recombinant leptin. Nat Genet. 1996;12(3):318-20.

10. Matkovic V, llich JZ, Skugor M, Badenhop NE, Goel P, Clairmont $A$, et al. Leptin is inversely related to age at menarche in human females. J Clin Endocrinol Metab. 1997;82(10):3239-45.

11. Bluher S, Mantzoros CS. Leptin in reproduction. Curr Opin Endocrinol Diabetes Obes. 2007; 14(6):458-64.

12. Morris DL, Rui L. Recent advances in understanding leptin signaling and leptin resistance. Am J Physiol Endocrinol Metab. 2009;297(6):E1247-59. 
13. Karlsson C, Lindell K, Svensson E, Bergh C, Lind P, Billig H, et al. Expression of functional leptin receptors in the human ovary. J Clin Endocrinol Metab. 1997;82(12):4144-8.

14. Benjamini Y, Hochberg Y. Controlling the false discovery rate: a practical and powerful approach to multiple testing. J R Stat Soc Ser B-Method. 1995;57(1):289-300.

15. Livak KJ, Schmittgen TD. Analysis of relative gene expression data using real-time quantitative PCR and the 2(T)(-Delta Delta C) method. Methods. $2001 ; 25(4): 402-8$.

16. Shafi R, Afzal MN. Status of serum leptin levels in females with infertility. Saudi Med J. 2008;29(10):1419-22.

17. Mercer JG, Moar KM, Hoggard N. Localization of leptin receptor $(\mathrm{Ob}-\mathrm{R})$ messenger ribonucleic acid in the rodent hindbrain. Endocrinology. 1998;139(1):29-34.

18. Apa R, Lanzone A, Mastrandrea M, Miceli F, Macchione E, Fulghesu $A M$, et al. Effect of pituitary adenylate cyclase-activating peptide on meiotic maturation in follicle-enclosed, cumulus-enclosed, and denuded rat oocytes. Biol Reprod. 1997;57(5): 1074-9.

19. Zhong $Y$, Kasson BG. Pituitary adenylate cyclase-activating polypeptide stimulates steroidogenesis and adenosine $3^{\prime}, 5^{\prime}$-monophosphate accumulation in cultured rat granulosa cells. Endocrinology. 1994; 135(1):207-13

20. Heindel JJ, Sneeden J, Powell CJ, Davis B, Culler MD. A novel hypothalamic peptide, pituitary adenylate cyclase-activating peptide, regulates the function of rat granulosa cells in vitro. Biol Reprod. 1996;54(3):523-30

21. Apfelbaum TF, Davidson NO, Glickman RM. Apolipoprotein A-IV synthesis in rat intestine: regulation by dietary triglyceride. Am J Physiol. 1987;252(5 Pt 1):G662-6.

22. Lee J, Park HJ, Choi HS, Kwon HB, Arimura A, Lee BJ, et al. Gonadotropin stimulation of pituitary adenylate cyclase-activating polypeptide (PACAP) messenger ribonucleic acid in the rat ovary and the role of PACAP as a follicle survival factor. Endocrinology. 1999; 140(2):818-26.

23. Green PH, Glickman RM, Riley JW, Quinet E. Human apolipoprotein A-IV. Intestinal origin and distribution in plasma. J Clin Invest. 1980;65(4):911-9.

24. Liu M, Doi T, Shen L, Woods SC, Seeley RJ, Zheng S, et al. Intestinal satiety protein apolipoprotein AIV is synthesized and regulated in rat hypothalamus. Am J Physiol Regul Integr Comp Physiol. $2001 ; 280(5):$ R1382-7.

25. Wypior G, Jeschke U, Kurpisz M, Szekeres-Bartho J. Expression of $\mathrm{CRH}, \mathrm{CRH}$-related peptide and $\mathrm{CRH}$ receptor in the ovary and potential CRH signalling pathways. J Reprod Immunol. 2011;90(1):67-73.
26. Walker CS, Conner AC, Poyner DR, Hay DL. Regulation of signal transduction by calcitonin gene-related peptide receptors. Trends Pharmacol Sci. 2010;31(10):476-83.

27. Lin X, Peter RE. Somatostatins and their receptors in fish. Comp Biochem Physiol B Biochem Mol Biol. 2001;129(2-3):543-50.

28. Patel YC. Somatostatin and its receptor family. Front Neuroendocrinol. 1999;20(3): 157-98.

29. Unger RH, Orci L. The essential role of glucagon in the pathogenesis of diabetes mellitus. Lancet. 1975;1 (7897):14-6.

30. Unger RH. Letter: glucagon in pathogenesis of diabetes. Lancet. 1975; 1 (7914): 1036-2.

31. Nestorovic N, Manojlovic-Stojanoski M, Ristic N, Sekulic M, Sosic-Jurjevic B, Filipović B, et al. Somatostatin-14 influences pituitary-ovarian axis in peripubertal rats. Histochem Cell Biol. 2008; 130(4):699-708.

32. Liu M, Shen L, Tso P. The role of enterostatin and apolipoprotein AIV on the control of food intake. Neuropeptides. 1999;33(5):425-33.

33. Brazeau $P$, Vale W, Burgus $R$, Ling $N$, Butcher $M$, Rivier J, et al. Hypothalamic polypeptide that inhibits the secretion of immunoreactive pituitary growth hormone. Science. 1973;179(4068):77-9.

34. Shen L, Tso P, Woods SC, Sakai RR, Davidson WS, Liu M. Hypothalamic apolipoprotein A-IV is regulated by leptin. Endocrinology. 2007; 148(6):2681-9.

35. Gerard N, Caillaud M, Martoriati A, Goudet G, Lalmanach AC. The interleukin-1 system and female reproduction. J Endocrinol. 2004; 180(2):203-12.

36. Chang $\mathrm{CL}$, Hsu SY. Roles of CLR/RAMP receptor signaling in reproduction and development. Curr Protein Pept Sci. $201314(5): 393-406$.

37. Wang FW, Zhang YM, Wang Z, Liu SM, Wang LY, Zhang $\mathrm{XL}$, et al. Calcitonin promotes mouse pre-implantation development: involvement of calcium mobilization and P38 mitogen-activated protein kinase activation. Reprod Domest Anim. 2013;48(3):382-9.

38. McLatchie LM, Fraser NJ, Main MJ, Wise A, Brown J, Thompson $N$, et al. RAMPs regulate the transport and ligand specificity of the calcitonin-receptor-like receptor. Nature. 1998;393(6683):333-9.

39. Vergetaki A, Jeschke U, Vrekoussis T, Taliouri E, Sabatini L, Papakonstanti EA, et al. Differential expression of $\mathrm{CRH}, \mathrm{UCN}$, CRHR 1 and CRHR2 in eutopic and ectopic endometrium of women with endometriosis. PLoS One. 2013;8(4):e62313. 